\title{
Lamin B
}

National Cancer Institute

\section{Source}

National Cancer Institute. Lamin B. NCI Thesaurus. Code C111790.

A family of class $V$ intermediate filaments that interact with nuclear membraneassociated proteins to form the nuclear lamina. This family of lamins has two members

(Lamin-B1 and-B2), are present in all cells and play a role in the disintegration and reformation of the nuclear envelop during mitosis. 